\title{
Vísbendingar um gæði lyfjameðferða aldraðra við innlögn á Landspítala
}

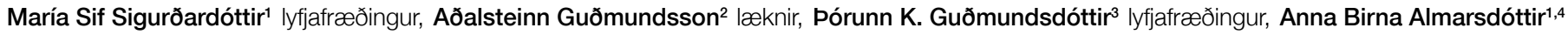 \\ lyfjafræðingur
}

\section{ÁGRIP}

Tilgangur: Algengi sjúkdóma eykst með hækkandi aldri og lyfjanotkun aldraðra er margföld í samanburði við yngri aldurshópa. Lyf geta minnkað einkenni sjúkdóma, bætt horfur og lífsgæði, en pau geta einnig leitt til lyfjatengdra vandamála sem eru tíðari og alvarlegri hjá öldruðum. Markmið rannsóknarinnar var að athuga vísbendingar um gæði lyfjameðferða aldraðra við innlögn á Landspítala.

Efniviður og aðferðir: Afturskyggn skoðun var gerð á sjúkraskrám 70 ára og eldri sem lögðust fyrirvaralaust inn á lyflækningasvið I og

bráðaöldrunarlækningadeild Landspítala árið 2007. Í úrtaki uppfylltu 913 sjúkraskrár skilyrði til úrvinnslu. Við mat á gæðum lyfjameðferða var stuðst við 15 lyfjamiðaða gæðavísa.

Niðurstöður: Meðalaldur var 80,9 ár og hlutfall kvenna 54,5\%. Meðalfjöldi lyfja við innlögn var 7,0 hjá konum en 6,5 hjá körlum ( $p=0,047)$. Hlutfall innlagna með einn eða fleiri gæðavísi var 48,4\%. Konur voru líklegri til að hafa gæðavísi en karlar (konur 56,2\%, karlar 39,9\%). Líkurnar jukust einnig með hækkandi aldri og fjölda lyfja.

Ályktanir: Gæðum lyfjameðferða aldraðra við innlögn á sjúkrahús virðist vera ábótavant í mörgum tilvikum. Nákvæmari mynd af umfangi vandans gæti fengist með framskyggnri rannsókn par sem tengsl lyfjameðferða við einkenni og ástæðu innlagnar yrðu metin jafnóðum. Einnig væri mikilvægt að kanna gæði lyfjameðferða utan sjúkrahúsa. Pannig fengist betri heildarmynd af gæðum lyfjameðferða aldraðra sem gæti nýst í umbótastarfi.

${ }^{1}$ Lyfjafræðideild HÍ, 2lyflækningasviði Landspítala,

${ }^{3}$ sjúkrahúsapóteki Landspítala, ${ }^{4}$ rannsóknastofnun um lyfjamál, HÍ.

Verkefnið var unnið við skjalasafn Landspítala og lyfjafræðideild Háskóla Íslands.

Fyrirspurnir: Anna Birna Almarsdóttir, annaba@hi.is

Barst: 3. maí 2011, sampykkt til birtingar 11. október 2011

Höfundar tiltaka engin hagsmunatengsl.

\section{Inngangur}

Öldruðum fjölgar hratt um allan heim. ${ }^{1,2}$ Framfarir í læknisfræði og próun nýrra lyfja hafa stuðlað að auknum lífslíkum ${ }^{1}$ og æ fleiri ná háum aldri. Áttræðum og eldri fjölgar nú um 4,0\% á hverju ári. Árið 2050 er búist við pví að um pað bil einn af hverjum fimm peirra sem eru 60 ára og eldri verði 80 ára eða eldri.

Par sem algengi langvinnra sjúkdóma eykst með aldri fjölgar ábendingum fyrir lyfjameðferð hjá öldruðum. Prátt fyrir að lyf séu oft lífsnauðsynleg geta pau einnig leitt til lyfjatengdra vandamála sem eru tíðari og alvarlegri hjá öldruðum en peim sem yngri eru. Ástæður pess eru meðal annars lífeðlisfræðilegar breytingar sem verða með aldrinum, aukin tíðni langvinnra sjúkdóma, fjöllyfjanotkun og óviðeigandi lyfjameðferð (inappropriate drug therapy). ${ }^{4}$ Einnig getur reynst erfitt að segja fyrir um verkun lyfja hjá pessum hópum par sem aldraðir, og pá sérstaklega háaldraðir og fjölveikir, hafa í mörgum tilvikum verið útilokaðir frá pátttöku í klínískum lyfjarannsóknum. ${ }^{1,5}$ Vegna pessara pátta er mikilvægt að fylgjast með og meta öryggi og gæði lyfjameðferða hjá pessum pjóðfélagshópi.

Gæðavísar hafa verið próaðir til pess að meta gæði lyfjameðferða. Peir eru skýrt skilgreindir og mælanlegir pannig að nota má pá sem undirstöðueiningar í mati á lyfjameðferð. ${ }^{6}$ Gæðavísar geta mælt tíðni atvika, svo sem ávísun ákveðinna lyfja, lyfjasamsetninga eða tilvik par sem viðeigandi meðferð er ekki veitt. Gæðavísar gefa ekki ótvíræð svör og eru oft einungis vísbending um gæðabrest.6, 7 Við val gæðavísa er yfirleitt fleira en eitt atriði tekið og pannig búið til safn af gæðavísum sem veitir heildarmynd af pví ferli sem verið er að skoða. Mikilvægt er að valdir séu pættir sem hafa forspárgildi um gæði og tengjast útkomu eða afleiðingu sem gefur færi á umbótavinnu. ${ }^{7}$

Lyfjamiðaðir gæðavísar eru oft valdir eftir peim lyfjum og lyfjasamsetningum sem ætti að forðast í lyfjameðferð aldraðra. ${ }^{8,} 9$ Óviðeigandi lyfjameðferð felur í sér notkun lyfja sem eru mjög líkleg til að geta valdið aukaverkunum eða skaðlegum milliverkunum. Að auki eru tilvik par sem upplýsingar skortir um öryggi á sama tíma og annar öruggari valkostur er í boði. ${ }^{4}$ Par sem röng lyfjameðferð getur haft neikvæð áhrif á heilsu og aukið efnahagslega byrði á sjúklingum og samfélögum pá er petta mikilvægt lýðheilsuverkefni. ${ }^{10}$

Nokkur skimunartæki hafa verið útbúin til pess að aðstoða lækna sem ávísa lyfjum og lyfjafræðinga til að bera kennsl á hugsanlega óviðeigandi lyfjaávísun (potentially inappropriate drug prescribing) og eru skilmerki Beers einn pekktasti og mest notaði mælikvarðinn í greininni. ${ }^{11-14}$ Sökum pess að margar rannsóknir á lyfjaávísunum aldraðra nota mismunandi mælitæki, eða samsetningu af mælitækjum, til pess að meta gæði, er erfitt að bera rannsóknir saman. Flestar benda pó í sömu átt: óviðeigandi lyfjaávísanir eru mikið vandamál á sviði heilbrigðispjónustu aldraðra. ${ }^{15}$

Nokkrar rannsóknir hafa verið gerðar sem benda til pess að óviðeigandi lyfjanotkun sé algengari meðal 
Tafla I. Gæðavísar lyfjanotkunar.

\begin{tabular}{|c|c|c|}
\hline Gæðavísir & Lyf og/eða ATC kóði & Ástæða \\
\hline $\begin{array}{l}\text { Príhringlaga } \\
\text { geðdeyfðarlyf }{ }^{4,6,11}\end{array}$ & $\begin{array}{l}\text { Amitryptilín (N06AA09), Trimipramín (N06AA06), Doxapín } \\
\text { (N06AA12), Chlomipramín (N06AA04) }\end{array}$ & $\begin{array}{l}\text { Sterk andkólínerg og róandi áhrif auka hættuna á hjáverkunum } \\
\text { hjá öldruðum, til dæmis vitrænni skerðingu, pvagteppu (karlar), } \\
\text { harðlífi, sjóntruflunum og byltum. }\end{array}$ \\
\hline Amitryptilín ${ }^{15,24}$ & N06AA09 & $\begin{array}{l}\text { Sterk andkólínerg og róandi áhrif auka hættuna á skertri } \\
\text { vitsmunastarfsemi í öldruðum. Aukin hætta á pvagteppu (karlar), } \\
\text { harðlífi, skertri sjón, byltum og beinbrotum. }\end{array}$ \\
\hline Fyrstu kynslóðar geðrofslyf $f^{4,6}$ & $\begin{array}{l}\text { Chlorpromazín (N05AA01), Chlorprotixene (N05AF03), } \\
\text { Levoprometazín (N05AA02), Prochlorperazín (N05AB04) }\end{array}$ & $\begin{array}{l}\text { Sterk andkólínerg og róandi áhrif. Geta valdið } \\
\text { utanstrýtueinkennum og stöðublóðprýstingsfalli. }\end{array}$ \\
\hline Langvirk benzódíazepín ${ }^{4,6,9,11}$ & Nitrazepam (N05CD02), Flunitrazepam (N05CD03) & $\begin{array}{l}\text { Hafa langan helmingunartíma og uppsöfnun peirra getur valdið } \\
\text { langvarandi róandi áhrifum og aukið hættu á byltum. }\end{array}$ \\
\hline Benzódíazepín 4,6,9 & N05BA, N05CD & Hætta á uppsöfnun og geta valdið byltum og vitrænni skerðingu. \\
\hline Fyrstu kynslóðar andhistamín ${ }^{4,6,9}$ & $\begin{array}{l}\text { Dexchlorphenamín (R06AB02), Promethazín (R06AD02), } \\
\text { Alimemazín (R06AD01), Hydroxycin (N05BB01) }\end{array}$ & $\begin{array}{l}\text { Sterk anskólínerg áhrif. Promethazín og Alimemazín geta } \\
\text { sérstaklega valdið utanstrýtueinkennum. }\end{array}$ \\
\hline $\begin{array}{l}\text { Beta blokkerar + ósérvirkir kalsíum } \\
\text { blokkerar }{ }^{4,6,9}\end{array}$ & $\begin{array}{l}\text { Beta blokkerar (C07A), Verapamíl (C08DA01) og Diltiazem } \\
\text { (C08DB01) }\end{array}$ & $\begin{array}{l}\text { Ósérvirkir kalsíum blokkerar í samsetningu með beta } \\
\text { blokkerum geta valdið skertri samdráttarhæfni hjartans og/eða } \\
\text { leiðslutruflunum. }\end{array}$ \\
\hline NSAID + warfarín $\mathrm{n}^{4,6,19,9}$ & NSAID (M01AB, M01AC, M01AE), warfarín (B01AA03) & Eykur hættu á blæðingum í meltingarvegi. \\
\hline $\begin{array}{l}\text { NSAID + ACE hemlar eđa } \\
\text { angíótensín II blokkar }\end{array}$ & $\begin{array}{l}\text { NSAID (M01AB, M01AC, M01AE), ACE hindrar (C09A, } \\
\text { C09B), A2 blokkerar (C09C, C09D) }\end{array}$ & $\begin{array}{l}\text { Getur valdið nýrnabilun í öldruðum sjúklingum, sérstaklega hjá } \\
\text { peim sem eru með æðakölkun, vökvatap eða samhliða notkun } \\
\text { pvagræsilyfja. }\end{array}$ \\
\hline NSAID + SSRI ${ }^{4,6}$ & NSAID (M01AB, M01AC, M01AE), SSRI (N06AB) & Eykur hættu á blæðingum í meltingarvegi. \\
\hline NSAID + pvagræsilyf $f^{4,6}$ & NSAID (M01AB, M01AC, M01AE), pvagræsilyf (C03) & $\begin{array}{l}\text { Getur dregið úr áhrifum pvagræsilyfja og leitt til versnandi } \\
\text { hjartabilunar. }\end{array}$ \\
\hline Aspirín + warfarín $^{19}$ & Aspirín (N02BA01, B01AC06), warfarín (B01AA03) & Aukin hætta á blæðingum. \\
\hline Svefnlyf ${ }^{24}$ & N05C & Aukin hætta á byltum og vitrænni skerðingu. \\
\hline Notkun priggja eða fleiri geðlyfja ${ }^{6}$ & Ópíóiđar (N02A), geðlyf (N05), punglyndislyf (N06A) & $\begin{array}{l}\text { Eykur hættuna á óhóflegum róandi áhrifum, milliverkunum og } \\
\text { óæskilegum áhrifum á miðtaugakerfið. }\end{array}$ \\
\hline $\begin{array}{l}\text { Notkun priggja eða fleiri geðlyfja-2 } \\
\text { (að undanskildum ópíóiðum) }{ }^{24}\end{array}$ & Geðlyf (N05), punglyndislyf (N06A) & $\begin{array}{l}\text { Eykur hættuna á óhóflegum róandi áhrifum, milliverkunum og } \\
\text { óæskilegum áhrifum á miðtaugakerfið. }\end{array}$ \\
\hline
\end{tabular}

kvenna en karla. ${ }^{16-19}$ Ástæðan fyrir pví gæti meðal annars verið sú að konur leita oftar eftir heilbrigðispjónustu og lýsa frekar einkennum en karlar. ${ }^{19-21}$ Einnig getur verið munur á einkennum sjúkdóma eftir kynjum, samskiptaháttum og samskiptum við lækna sem getur að einhverju leyti skýrt pennan kynjamun. ${ }^{19}$

Markmið pessarar rannsóknar var að athuga algengi vísbendinga um gæði lyfjameðferða einstaklinga 70 ára og eldri við innlögn á lyflækningadeildir og bráðaöldrunarlækningadeild. Gæðin voru metin með völdum gæðavísum sem gefa til kynna hugsanlega óviðeigandi lyfjameðferð. Athugað var hvort mismunur væri á gæðum eftir kyni og aldri.

\section{Efniviður og aðferðir}

Рýðið í rannsókninni voru einstaklingar 70 ára og eldri sem lögðust fyrirvaralaust inn á lyflækningasvið I og bráðaöldrunarlækningadeild (B4) á öldrunarsviði Landspítala árið 2007. Slembiúrtak 1500 sjúklinga var tekið úr öllum innlögnum í legukerfi sjúkrahússins fyrir petta tímabil. Í úrtakinu var einungis tekin með ein innlögn fyrir hvern sjúkling og var valin fyrsta innlögn fyrir hverja kennitölu. Í rannsókninni var farið yfir 818 sjúkraskrár á kerfisbundinn hátt. Sjúklingum sem lentu í úrtaki var raðað eftir fæðingardegi pannig að sjúkraskrá peirra sem áttu afmæli 1. janúar ár hvert voru rýndar fyrst og sjúkraskrár elstu sjúklinganna teknar fyrst á hverjum afmælisdegi og svo framvegis. Fjöldi rýndra sjúkraskráa takmarkaðist við pann tíma sem rýnarnir höfðu til að ljúka meistaraprófi í lyfjafræði.

Af 818 sjúkraskrám sem farið var yfir voru 184 útilokaðar. Í peim hópi voru sjúkraskrár sem notaðar voru í forprófun rannsóknar $(\mathrm{N}=20)$, sjúkraskrár sem notaðar voru í samanburði milli rýna (interrater reliability, $\mathrm{N}=22$ ), par sem ártal innlagnar var rangt $(\mathrm{N}=31)$, svið sem átti ekki að vera í úrtaki $(\mathrm{N}=1)$, skrár í láni $(\mathrm{N}=28)$, skrár sem fundust ekki $(\mathrm{N}=8)$ eða skortur var á upplýsingum $(\mathrm{N}=74)$. Að auki var stuðst við 279 rýndar sjúkraskrár úr fyrri rannsókn á sama úrtaki. ${ }^{22}$ Rýndar voru 22 sjúkraskrár úr fyrri rannsókn og reyndist gott samræmi vera á milli skráningar rannsakenda $(\mathrm{r}=0,995)$. Sjúkraskrárupplýsingar voru pví nýttar úr samtals 913 innlögnum.

Skráningarkerfi var próað fyrir gagnasöfnunina. Рað hélt utan um ástæðu komu, athugasemdir lækna, lyf við komu, fjölda lyfja við komu og aðrar athugasemdir. Gögn um aldur, kyn og útskriftargreiningar voru fengin úr legukerfi Landspítala.

Við yfirlestur sjúkraskrár var bráđasjúkraskrá lesin, læknabréf af bráđamóttöku, innlagnarnóta á deild, lyfjablöð og útskriftarnóta af deild. Flett var upp í rafrænni sjúkraskrá (Sögukerfi) pegar einhver af áour nefndum gögnum voru ekki í pappírssjúkraskrá. 


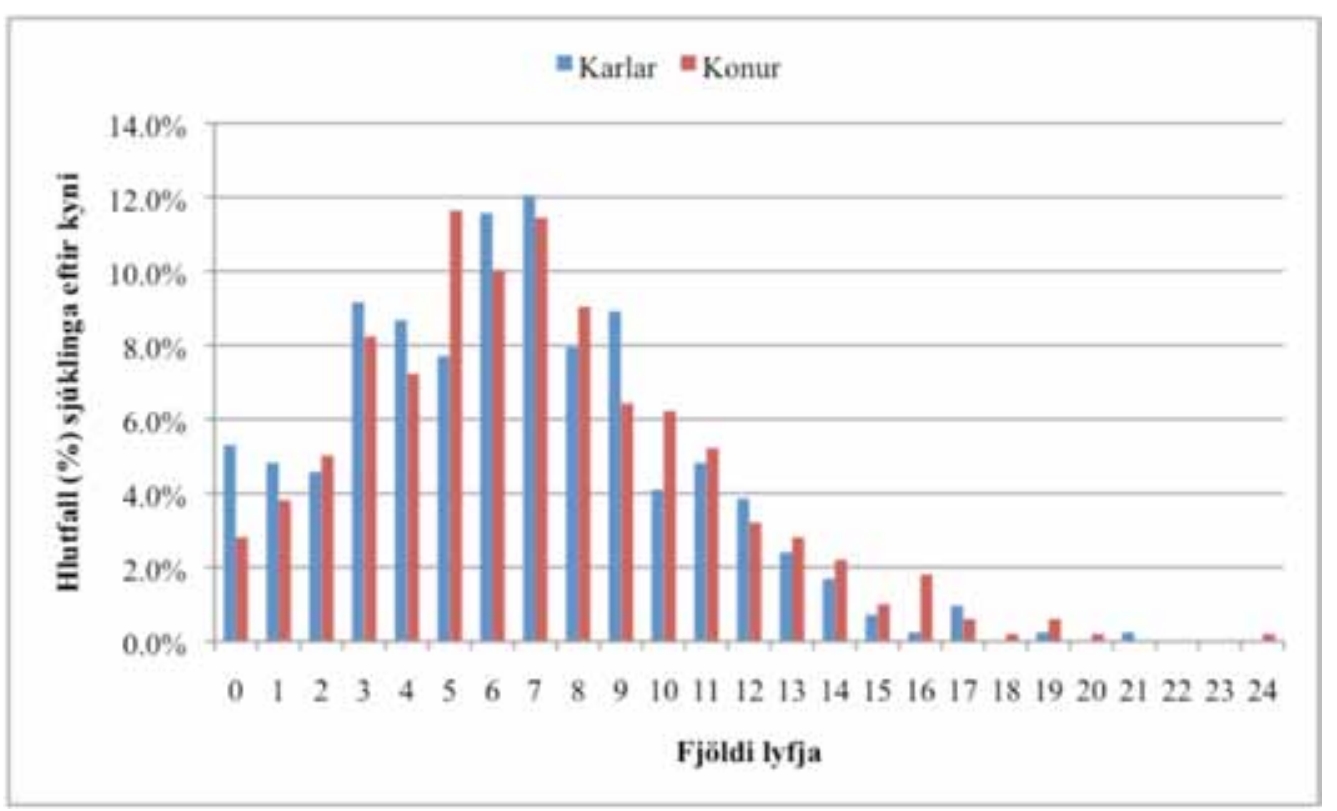

Mynd 1. Hlutfall sjúklinga eftir fjölda lyfja við innlögn, skipt eftir kyni.

Ef innlagnarnóta á deild, lyfjablöð eða útskriftarnóta af deild var ekki til staðar í pappírssjúkraskrá eða í Sögu, var innlögn ekki tekin með. Í mörgum tilfellum var ekki hægt að finna bæði bráðasjúkraskrá og læknabréf af bráðamóttöku. Ef hvorugt fannst var innlögn ekki tekin með. Lyf við komu voru skráð í samræmi við skráningu í bráđasjúkraskrá, læknabréfi af bráđamóttöku, innlagnarnótu og/eða lyfjablöðum. Einungis var skráð heiti lyfs og ATC-númer en hvorki skammtur né styrkur.

Gæðavísar sem sneru eingöngu að lyfjum voru valdir. Gerð var heimildaleit og birtir lyfjamiðaðir gæðavísar fundnir. Einn höfunda, sérfræðingur í öldrunarlækningum, lagði mat á gildi peirra og nothæfi í pessari rannsókn. Í töflu I má sjá gæðavísana sem notaðir voru í rannsókninni ásamt rökstuðningi fyrir vali peirra.

Til samanburðar var t-próf notað á samfelldum breytum en annars $\chi^{2}$-próf. Til pess að mæla fylgni milli gæðavísa og ýmissa breyta var notuð einbreytudreifigreining, ANOVA-, eða $\chi^{2}$-próf pegar ekki var um samfelldar breytur að ræða. Pegar ANOVAprófi var beitt var aðferð Bonferroni notuð, til að leiðrétta fyrir margfaldan samanburð. Tvíundargreining (logistic regression) var gerð til pess að meta samband milli ákveðinna breyta og líkurnar á að hafa gæðavísi. Tölfræðileg marktækni var í öllum greiningum miðuð við $\mathrm{p}<0,05$. Við tölfræðilega úrvinnslu var notað Statistical Package for the Social Sciences, SPSS 18.0. Önnur úrvinnsla var gerð í Excel 2007 töflureikni og í skráningarkerfinu sem próað var fyrir pessa rannsókn.

Tilskilin leyfi fyrir rannsókninni fengust hjá Persónuvernd og siðanefnd Landspítala.

\section{Niðurstöður}

Hlutfall kvenna í rannsókninni var 54,5\%. Meðalaldur peirra 913 sjúklinga sem áttu sjúkraskrár í rannsókninni var 80,9 ár. Meðalaldur kvenna (81,9 ár) var marktækt hærri $(\mathrm{p}<0,001)$ en karla (79,7 ár). Meðalfjöldi lyfja við innlögn hjá konum var 7,0 lyf en hjá körlum 6,5 lyf og var munurinn tölfræðilega marktækur $(\mathrm{p}=0,047)$.

Mynd 1 sýnir fjölda lyfja eftir kyni við innlögn. Meðalfjöldi lyfja var 6,8 lyf (spönn 0-24). Algengast var að konur væru á fimm lyfjum og karlar á sjö lyfjum. Við innlögn voru 22 (5,3\%) karlar og 14 (2,8\%) konur ekki á neinum lyfjum.

Algengustu lyfjaflokkarnir (ATC) hjá báðum kynjum voru flokkar A (meltingarfæra- og efnaskiptalyf), B (blóðlyf), C (hjartaog æðasjúkdómalyf) og N (tauga- og geðlyf). Algengustu flokkar meðal kvenna voru flokkar C (86,1\%), N (71,1\%), A $(57,4 \%)$ og B

Tafla II. Fjöldi sjúklinga með gæðavísa eftir kyni og hlutfall i hverjum hópi.

\begin{tabular}{|c|c|c|c|c|}
\hline Gæðavísar & $\begin{array}{l}\text { Konur } \\
(n=498)\end{array}$ & $\begin{array}{l}\text { Karlar } \\
(\mathrm{n}=415)\end{array}$ & $\begin{array}{c}\text { Heild } \\
(n=913)\end{array}$ & p-gildi \\
\hline $\begin{array}{l}\text { Príhringlaga } \\
\text { geðdeyfðarlyf }\end{array}$ & $24(4,8 \%)$ & $7(1,7 \%)$ & $31(3,4 \%)$ & 0,009 \\
\hline Amitryptilín & $14(2,8 \%)$ & $7(1,7 \%)$ & $21(2,3 \%)$ & 0,259 \\
\hline $\begin{array}{l}\text { Fyrstu kynslóðar } \\
\text { geðrofslyf }\end{array}$ & $13(2,6 \%)$ & $9(2,2 \%)$ & $22(2,4 \%)$ & 0,665 \\
\hline $\begin{array}{l}\text { Langvirk } \\
\text { benzódíazepín }\end{array}$ & $8(1,6 \%)$ & $7(1,7 \%)$ & $15(1,6 \%)$ & 0,924 \\
\hline Benzódíazepín & $115(23,1 \%)$ & $58(14,0 \%)$ & $173(18,9 \%)$ & 0,000 \\
\hline $\begin{array}{l}\text { Fyrstu kynslóðar } \\
\text { andhistamín }\end{array}$ & $21(4,2 \%)$ & $12(2,9 \%)$ & $33(3,6 \%)$ & 0,285 \\
\hline $\begin{array}{l}\text { Beta blokkerar + } \\
\text { ósérvirkir kalsíum } \\
\text { blokkerar }\end{array}$ & $7(1,4 \%)$ & $6(1,4 \%)$ & $13(1,4 \%)$ & 0,959 \\
\hline NSAID + Warfarín & $8(1,6 \%)$ & $4(1,0 \%)$ & $12(1,3 \%)$ & 0,396 \\
\hline $\begin{array}{l}\text { NSAID + ACE hemlar } \\
\text { eđa Angiotensín II } \\
\text { blokkar }\end{array}$ & $17(3,4 \%)$ & $7(1,7 \%)$ & $24(2,6 \%)$ & 0,104 \\
\hline NSAID + SSRI & $9(1,8 \%)$ & $3(0,7 \%)$ & $12(1,3 \%)$ & 0,152 \\
\hline NSAID + Pvagræsilyf & $19(3,8 \%)$ & $7(1,7 \%)$ & $26(2,8 \%)$ & 0,054 \\
\hline Aspirín + Warfarín & $15(3,0 \%)$ & $26(6,3 \%)$ & $41(4,5 \%)$ & 0,018 \\
\hline $\begin{array}{l}\text { Notkun priggja eða } \\
\text { fleiri geðlyfja }\end{array}$ & $84(16,9 \%)$ & $37(8,9 \%)$ & $121(13,3 \%)$ & 0,000 \\
\hline $\begin{array}{l}\text { Notkun priggja eða } \\
\text { fleiri geðlyfja-2 }\end{array}$ & $69(13,9 \%)$ & $31(7,5 \%)$ & $100(11,0 \%)$ & 0,002 \\
\hline Svefnlyf & $204(41,0 \%)$ & $103(24,8 \%)$ & $307(33,6 \%)$ & 0,000 \\
\hline
\end{tabular}


Tafla III. Meðalfjöldi lyfja eftir fjölda gæðavisa. Gæðavísunum er skipt i fjögur gæðavísabil.

\begin{tabular}{cccc}
\hline Fjöldi gæðavísa & Meðalfjöldi lyfja & Staðalfrávik & 95\% öryggisbil \\
\hline 0 & 4,97 & 3,11 & $4,69-5,25$ \\
\hline 1 & 7,76 & 3,26 & $7,33-8,19$ \\
\hline $2-3$ & 8,46 & 3,78 & $7,81-9,11$ \\
\hline$\geq 4$ & 11,28 & 3,94 & $10,45-12,11$ \\
\hline
\end{tabular}

(57,0\%). Algengustu flokkar meðal karla voru flokkar C (82,2\%), B $(69,6 \%), N(52,8 \%)$ og A $(53,3 \%)$. Áberandi kynjamunur var á notkun lyfja í flokkum $\mathrm{N}$ og $\mathrm{B}$. Konur notuðu fleiri lyf úr flokki $\mathrm{N}$, en karlar notuðu fleiri lyf úr flokki B.

Við innlögn voru konur líklegri til að hafa gæðavísi en karlar. Hlutfall sjúklinga með einn eða fleiri gæðavísi var 48,4\% (konur 56,2\%, karlar 39,9\%). Við innlögn voru 43,8\% kvenna og 61,0\% karla án gæðavísis og voru pví líklega að nota lyf sem talin eru hæfileg. Hlutfallið fór síðan lækkandi hjá báðum kynjum pegar fjöldi gæðavísa jókst. Mestur fjöldi gæðavísa á mann var átta en prír einstaklingar voru með pann fjölda gæðavísa.

Á öllum aldursbilum (70-74 ára, 75-79 ára, 80-84 ára og 85 ára og eldri) voru flestir með engan gæðavísi. Hlutfall sjúklinga fór síðan minnkandi pegar fjöldi gæðavísa jókst og á pað við öll aldursbilin. Tölfræðilega marktækur munur reyndist vera á milli aldursbila hvað varðar fjölda gæðavísa $(p=0,010)$. Peir sem voru á aldursbilinu 85 ára og eldri voru líklegri til að hafa einn eða fleiri gæðavísa.

Tafla II sýnir fjölda sjúklinga með gæðavísa eftir kyni. Í sex af 15 gæðavísum var tölfræðilega marktækur munur milli kynja. Konur voru oftar með fimm af pessum sex gæðavísum. Algengasti gæðavísir hjá báðum kynjum voru svefnlyf (41,0\% kvenna, 24,8\% karla).

Tafla III sýnir meðalfjölda lyfja eftir fjölda gæðavísa. Gæðavísunum er skipt í fjögur gæðavísabil í samanburðinum. ANOVApróf sýndi að tölfræðilega marktækur munur $(\mathrm{F}=117,6 ; \mathrm{p}<0,001)$ var á milli allra gæðavísabilanna með tilliti til meðalfjölda lyfja, nema pegar einn gæðavísir var borinn saman við tvo til prjá gæðavísa $(\mathrm{p}=0,339)$.

Tafla IV sýnir niðurstöður tvíundargreiningar á sambandi aldurs, kyns og fjölda lyfja við líkur á að hafa einn eða fleiri gæðavísa. Allar óháðu breyturnar, aldur, kyn og fjöldi lyfja, hafa tölfræðilega marktækan stuðul. Helmingi minni líkur eru á að karlar séu með gæðavísi (OR=0,497) ef leiðrétt er fyrir aldri og fjölda lyfja. Fyrir hvert aldursár eru um pað bil 3\% hærri líkur

Tafla IV. Tvíundargreining á sambandi aldurs, kyns og fjölda lyfja við líkur á að hafa gæðavísi.

\begin{tabular}{lccc}
\multicolumn{1}{c}{ Breytur } & Stuðull & p-gildi & OR \\
\hline Aldur í árum & 0,030 & 0,012 & 1,031 \\
\hline Karlkyn & $-0,699$ & 0,000 & 0,497 \\
\hline Fjöldi lyfja við innlögn & 0,325 & 0,000 & 1,384 \\
\hline Fasti & $-4,366$ & 0,000 & 0,013 \\
\hline$\chi^{2}$ (p-gildi) & $263,522(p=0,000)$ & & \\
\hline $\mathrm{N}$ & 913 & & \\
\hline Nagelkerke R square & 0,334 & & \\
\hline
\end{tabular}

á að hafa gæðavísi $(\mathrm{OR}=1,031)$ pegar leiðrétt hefur verið fyrir kyni og fjölda lyfja. Líkur á að hafa gæðavísi aukast um $40 \%$ fyrir hvert lyf sem bætist við fjölda lyfja $(\mathrm{OR}=1,384)$ eftir að leiðrétt er fyrir kyni og aldri. Kí-kvaðrat próf sýndi fram á að líkanið var tölfræðilega marktækt $(\mathrm{p}<0,001)$. Einnig var námundað $R^{2}$ (Nagelkerke $R$ square) ekki lágt $(0,334)$, sem gefur til kynna að líkanið geti skýrt að nokkrum hluta líkurnar á pví að vera með gæðavísi.

\section{Umræður}

Gæði lyfjameðferða meðal aldraðra hafa ekki verið rannsökuð að ráði á Íslandi og hafa skilyrðagæðavísar fyrir lyfjameðferð við innlögn á sjúkrahús ekki verið skoðaðir áður með jafn víðtækum hætti og gert var í pessari rannsókn. Farið var yfir margar sjúkraskrár og eykur pað styrk rannsóknar. Rafrænt skráningarkerfi hélt utan um gögn sem skráð voru í par til gerðum gagnagrunni. Kerfið var einnig notað við úrvinnslu gagnanna. Notkun skráningarkerfis dregur úr hættunni á mistökum við skráningu og úrvinnslu.

Við innlögn voru konur á tölfræðilega marktækt fleiri lyfjum en karlar. Í rannsókn sem gerð var á Íslandi árið 1995 meðal 75 ára og eldri sem lögðust fyrirvaralaust inn á lyflækningadeildir Borgarspítalans, var meðalfjöldi lyfja hjá konum 5,8 lyf en 6,6 lyf hjá körlum. ${ }^{23}$ Í samanburði við pessa rannsókn kemur í ljós að á peim rúma áratug sem er á milli rannsóknanna hefur meðalfjöldi lyfja við innlögn hækkað meðal kvenna en er sambærilegur meðal karla.

Í rannsókn sem studdist við sænska lyfjagagnagrunninn fyrir einstaklinga 75-89 ára árið 2005 kom fram að konur voru oftar á hugsanlega óviðeigandi lyfjameðferð (24,6\% hjá konum, 19,3\% hjá körlum). Pessi munur á kynjunum var einnig til staðar eftir að búið var að leiðrétta fyrir aldri, menntunarstigi og fjölda lyfja. ${ }^{19}$ Í pessari rannsókn kom pessi kynjamunur einnig fram, en talsvert hærra hlutfall hjá báðum kynjum var með einn eða fleiri gæðavísi. Ástæðan fyrir hærra hlutfalli sjúklinga á hugsanlega óviðeigandi lyfjameðferð í pessari rannsókn er líklega sú að sænska rannsóknin náði til alls pýðisins en pessi rannsókn tók aðeins til peirra sem purftu á innlögn að halda.

Konur voru oftar með fimm af peim sex gæðavísum par sem tölfræðilega marktækur munur kom fram. Karlar höfðu oftar gæðavísinn "aspirín + warfarín". Petta er í samræmi við niðurstöður rannsóknar úr sænska lyfjagagnagrunninum en par voru karlar oftar með gæðavísinn „hugsanlegar alvarlegar milliverkanir" sem samanstóð af lyfjasamsetningunum aspirín + NSAID, aspirín + warfarín og warfarín + NSAID. ${ }^{19}$

Gæðavísirinn „,svefnlyf“ var algengasti gæðavísirinn hjá báðum kynjum. Konur voru marktækt oftar með pennan gæðavísi. Fleiri konur en karlar kvarta undan svefnerfiðleikum og eykst algengi kvartana með hækkandi aldri. Algengi ávísana á svefnlyf eykst með hækkandi aldri og er ávísun á pessi lyf meiri hjá konum er körlum. ${ }^{20}$ Í rannsókninni var gæðavísirinn "svefnlyf skilgreindur sem N05C. Í íslenskri rannsókn sem kannaði algengi geðlyfjanotkunar 70 ára og eldri í lyfjagagnagrunni landlæknisembættisins kom fram að 49,0\% kvenna og 33,4\% karla leystu út lyf í flokki N05C á Íslandi árið 2006. ${ }^{24}$ Ástæðan fyrir pví að lægra hlutfall beggja kynja kom fram í pessari rannsókn 
gæti verið sú að svefnlyf eru oft tekin eftir pörfum, eða að um vanskráningu sé að ræða. Prátt fyrir mögulega vanskráningu svefnlyfja við innlögn var hátt hlutfall sjúklinga með pennan gæðavísi (33,6\%). Notkun róandi lyfja og svefnlyfja er mikil og er margt sem bendir til pess að pau séu ofnotuð meðal aldraðra. ${ }^{23}$

Tveir gæðavísar voru notaðir fyrir samhliða notkun priggja eða fleiri geðlyfja. Gæðavísirinn "notkun priggja eða fleiri geðlyfja” var skilgreindur sem notkun lyfja í flokkunum N02A, N05 og N06A. Par sem flokkur N02A nær yfir verkjalyf, morfín, kódein og fleiri, var ákveðið að hafa einnig annan gæðavísi "notkun priggja eða fleiri geðlyfja 2" sem tekur ekki N02Aflokkinn (ópíóía) með. Í rannsókninni sem byggði á gögnum úr lyfjagagnagrunni landlæknisembættisins var notkun margra geðlyfja samtímis metin með pví að greina fjölda einstaklinga 70 ára og eldri sem leysti út prjú eða fleiri mismunandi lyf úr flokkum N05A, N05B, N05C og N06A á priggja mánaða tímabili á árinu 2006. Par kom fram að hlutfall kvenna sem leysti út prjú eða fleiri geðlyf var $8,5 \%$ og karla $4,4 \%{ }^{24}$ Hærra hlutfall kom fram í pessari rannsókn og ástæðan fyrir pví gæti verið að í rannsókninni úr lyfjagagnagrunninum var verið að skoða 70 ára og eldri utan stofnana en í pessari rannsókn er um hóp 70 ára og eldri að ræða sem leggjast inn á sjúkrahús og má pví gera ráð fyrir að um veikari hóp sé að ræða. Í báðum rannsóknunum kemur pó fram að hlutfall kvenna á premur eða fleiri geðlyfjum er hærra en hlutfall karla, sem er í samræmi við erlendar rannsóknir. ${ }^{19}$

Pegar fjöldi gæðavísanna (0, 1, 2-3 og 4 eða fleiri) var borinn saman við meðalfjölda lyfja, reyndist vera tölfræðilega marktækur munur, nema pegar einn gæðavísir var borinn saman við tvo til prjá gæðavísa. Petta stafar líklega af skörun milli gæðavísa. Til dæmis er einstaklingur á amitryptilíni með tvo gæðavísa tengda pví lyfi, gæðavísana "príhringlaga geðdeyfðarlyf" og „amitryptilín“. Eftir pví sem sjúklingar eru á fleiri lyfjum eru peir líklegri til að hafa gæðavísi. Erlendar rannsóknir hafa sýnt að sjúklingar á mörgum lyfjum eru í mestri hættu á að vera á hugsanlega óviðeigandi lyfjameðferð. ${ }^{4,11,25}$

Í fyrrnefndri sænskri rannsókn frá 2005 var leiðrétt fyrir aldri, menntunarstigi og fjölda lyfja en konur voru samt líklegri til pess að vera á hugsanlega óviðeigandi lyfjameðferð en karlar. Sama má segja um pessa rannsókn eftir að leiðrétt hafði verið fyrir aldri og fjölda lyfja. Í pessari rannsókn kom pessi kynjamunur einnig fram, en talsvert hærra hlutfall hjá báðum kynjum var með einn eða fleiri gæðavísi. Par sem leiðrétt var fyrir fjölda lyfja, eins og gert var í pessari rannsókn, gat meiri notkun kvenna á heilbrigðispjónustu og að pær lýsa oftar sjúkdómseinkennum ekki að fullu, skýrt kynjamun á gæðum lyfjameðferða. Höfundar sænsku rannsóknarinnar nefna að skoða mætti kynjamuninn út frá hjúskaparstöðu og heimilisaðstæðum og telja mögulegt að mismunandi einkenni sjúkdóma milli kynja, samskiptahættir og mismunur á samskiptum sjúklings og læknis geti haft pessi áhrif. ${ }^{19}$

Rannsókn pessi, sem byggði á söfnun gagna úr sjúkraskrám, gefur vísbendingu um að skráningu lyfja við komu eða umsýslu gagna sé ábótavant. Sleppa purfti 9,0\% sjúkraskráa vegna skorts á gögnum en alls uppfylltu 22,5\% sjúkraskráa ekki skilyrði rannsóknar. Petta gæti leitt til upplýsingabjaga ef pær sjúkraskrár sem ekki var hægt að rýna voru vegna sjúklinga sem voru að einhverju leyti frábrugðnir peim sem hægt var að safna gögnum um. Hugsast gæti að pær sjúkraskrár sem ekki tókst að rýna væru vegna sjúklinga með flóknari sjúkdóma og meiri lyfjanotkun. раð gæti leitt til vanmats á algengi á gæðabresti lyfjanotkunar pýðisins.

Í rannsókninni var hvorki tekið tillit til skammtastærða, vanmeðhöndlunar né meðferðarheldni, en lág meðferðarheldni er mikið vandamál meðal aldraðra og getur verið $26-59 \%$ í pessum pjóðfélagshópi. ${ }^{26}$ Enn einn veikleiki var að ekki var tekið tillit til pess að hver og einn gæðavísir getur falið í sér mismikla áhættu á rangri lyfjameðferð. Einnig er fjöldi gæðavísa að einhverju leyti oftalinn vegna skörunar á gæðavísum eins og áður hefur komið fram.

Par sem einungis lyfjaupplýsingum var safnað, var notast við lyfjamiðaða gæðavísa í pessari rannsókn. Gæðavísarnir sem valdir voru miðast allir við lyf eða lyfjasamsetningar sem mælt hefur verið með að forðast eða lágmarka í lyfjameðferð aldraðra. Gæðavísar sem meta vanmeðhöndlun með lyfjum hafa einnig verið hannaðir, en vanmeðhöndlun getur haft alvarlegar afleiðingar í för með sér. 25,27 Í pessari rannsókn var ekki tekið tillit til vanmeðhöndlunar við val á gæðavísum. Einnig er rétt að benda á, eins og komið hefur fram, að notkun gæðavísa við mat á gæðum er einungis vísbending, ekki alhæfing, um að gæðabrestur geti verið til staðar. ${ }^{7}$ Í sumum tilvikum getur legið fyrir rökstuðningur fyrir notkun ákveðinna lyfja og lyfjasamsetninga. Petta getur til dæmis átt við um tímabundna notkun svefnlyfja.

Niðurstöður rannsóknarinnar benda til pess að gæðum í lyfjameðferð aldraðra sé ábótavant og að betur megi gera í eftirfylgd og klínískri ákvarðanatöku. Konur virðast líklegri til að vera á hugsanlega óviðeigandi lyfjameðferð. Einnig aukast líkur á hugsanlega óviðeigandi lyfjameðferð með aldri og fjölda lyfja. Gæðavísarnir voru flestir fengnir úr erlendum rannsóknum en hafa ekki verið áreiðanleikaprófaðir í heild sinni sem mælitæki. Æskilegra væri að nota áreiðanleikaprófað mælitæki ef til framhaldsrannsókna kæmi, auk pess sem slíkt auðveldaði samanburð við erlendar rannsóknir. Einnig gæti verið áhugavert аð skoða gæði lyfjameðferða aldraðra í framsýnni rannsókn par sem sjúkdómsgreiningar og einkenni eru skoðuð og tengsl lyfjameðferðar við ástæðu innlagnar metin jafnóðum.

\section{Pakkir}

Steinar Hugi Sigurðarson hugbúnaðarverkfræðingur fær pakkir fyrir forritun á skráningarkerfi og aðstoð við tölvuúrvinnslu. Guðrún Pengilsdóttir lyfjafræðingur fær pakkir fyrir rýningu á hluta sjúkraskráa. Einnig fær María Heimisdóttir sviðsstjóri hagog upplýsingasviðs og starfsmenn hagdeildar Landspítala pakkir fyrir að greiða götu rannsóknarfólks við gagnasöfnun. 


\section{Heimildir}

1. Shi S, Morike K, Klotz U. The clinical implications of ageing for rational drug therapy. Eur J Clin Pharmacol 2008; 64: 183-99.

2. Fialova D, Onder G. Medication errors in elderly people: contributing factors and future perspectives. Brit J Clin Pharmacol 2009; 67: 641-5.

3. United Nations. World Population Ageing 2009. United Nations, New York 2009.

4. Brekke M, Rognstad S, Straand J, et al. Pharmacologically inappropriate prescriptions for elderly patients in general practice: How common? Baseline data from The Prescription Peer Academic Detailing (Rx-PAD) study. Scand J Prim Health Care 2008; 26: 80-5.

5. Crome P. What's different about older people. Toxicology 2003; 192: 49-54.

6. Straand J, Fetveit A, Rognstad S, Gjelstad S, Brekke M, Dalen I. A cluster-randomized educational intervention to reduce inappropriate prescription patterns for elderly patients in general practice - The Prescription Peer Academic Detailing (Rx-PAD) study [NCT00281450]. BMC Health Serv Res 2006; 6: 72.

7. Heimisdóttir M. Mælingar á gæðum. Læknablaðið 2005 91: 44.

8. Fick DM, Cooper JW, Wade WE, Waller JL, Maclean JR, Beers $\mathrm{MH}$. Updating the beers criteria for potentially inappropriate medication use in older adults - Results of a US consensus panel of experts. Arch Int Med 2003; 163: 2716-24.
9. Gallagher P, Ryan C, Byrne S, Kennedy J, O'Mahony D. STOPP (Screening Tool of Older Person's Prescriptions) and START (Screening Tool to Alert Doctors to Right Treatment). Consensus validation. Int J Clin Pharmacol Ther 2008; 46: 72-83.

10. Spinewine A, Schmader KE, Barber N, et al. Prescribing in elderly people 1 - Appropriate prescribing in elderly people: how well can it be measured and optimised? Lancet 2007; 370: 173-84

11. Page RL, Linnebur SA, Bryant LL, Ruscin JM. Inappropriate prescribing in the hospitalized elderly patient: Defining the problem, evaluation tools, and possible solutions. Clin Interv Aging 2010; 5: 75-87.

12. Roth MT, Weinberger M, Campbell WH. Measuring the Quality of Medication Use in Older Adults. J Am Geriatr Soc 2009; 57: 1096-102.

13. Levy HB, Marcus EL, Christen C. Beyond the beers criteria: a comparative Overview of Explicit Criteria. Ann Pharmacother 2010; 44: 1968-75.

14. Beers $\mathrm{MH}$, Ouslander JG, Rollingher I, Reuben DB, Brooks J, Beck JC. Explicit criteria for for determining inappropriate medication use in nursing-home residents. Arch Intern Med 1991; 151: 1825-32.

15. Straand J, Rokstad KS. Elderly patients in general practice: diagnoses, drugs and inappropriate prescriptions. A report from the More \& Romsdal Prescription Study. Fam Pract 1999; 16: 380-8.

16. Aparasu RR, Mort JR. Inappropriate prescribing for the elderly: Beers criteria-based review. Ann Pharmacother 2000; 34: 338-46.
17. Gurwitz JH. The age/gender interface in geriatric pharmacotherapy. J Womens Health 2005; 14: 68-72.

18. Johnell K, Fastbom J, Rosen M, Leimanis A. Inappropriate drug use in the elderly: a nationwide register-based study. Ann Pharmacother 2007; 41: 1243-8.

19. Johnell K, Weitoft GR, Fastborn J. Sex Differences in Inappropriate Drug Use: a Register-Based Study of Over 600,000 Older People. Ann Pharmacother 2009; 43: 1233-8.

20. Helgason T, Tómasson K, Zoëga T. Algengi og dreifing notkunar geðdeyfðar-, kvíða- og svefnlyfja. Læknablaðið 2003; 89: 15-22.

21. Bertakis KD. The influence of gender on the doctor-patient interaction. Patient Educ Counsel 2009; 76: 356-60.

22. Pengilsdóttir G. Lyf sem orsök innlagna - vísbendingar 1 sjúkraskrám [meistaraprófsritgerð]. Lyfjafræðideild Háskóla Íslands, 2009.

23. Samúelsson S, Björnsson S, Jóhannesson BH, Jónsson PV. Lyfjanotkun aldraðra á bráđasjúkrahúsi - Aukaverkanir og gæðavísar. Læknablaðið 2000; 86: 11-6.

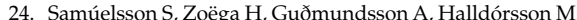
Algengi geðlyfjanotkunar eldri Íslendinga utan stofnana. Læknablaðið 2009; 95: 11-7.

25. Ryan C, O'Mahony D, Byrne S. Application of STOPP and START Criteria: Interrater Reliability Among Pharmacists. Ann Pharmacother 2009; 43: 1239-44.

26. Banning M. A review of interventions used to improve adherence to medication in older people. Int J Nurs Studies 2009; 46: 1505-15.

27. Rochon PA, Gurwitz JH. Prescribing for seniors - Neither too much nor too little. JAMA 1999; 282: 113-5.

\section{ENGLISH SUMMARY}

\section{Quality indicators of drug therapy at hospital admission among elderly patients}

Sigurðardóttir MS, Guðmundsson A, Guðmundsdóttir PK, Almarsdóttir AB

Objective: Increased morbidity and higher prevalence of medication use commonly coexists among the elderly. When managed appropriately, older patients can benefit from drug therapy. However, drug related problems are more frequent and more serious in the elderly. The aim of the study was to assess the quality of medication use in older people at hospital admission.

Material and methods: A retrospective medical record review was performed for patients 70 years and older who had an unplanned admission to the internal medicine and geriatric units at Landspitali University Hospital in 2007. Among the sampled medical records, 913 met inclusion criteria. Assessment was carried out using 15 drug-specific quality indicators.

Results: Mean age was 80.9 years and $54.5 \%$ were women. Mean number of drugs at admission was 7.0 for women and 6.5 for men ( $p=0.047$ ). The prevalence of having one or more quality indicators on admission was $48.4 \%$. Women were more likely to have a quality indicator than men (women $56.2 \%$, men $39.9 \%$ ). The probability also increased with increasing age and number of drugs.

Conclusions: The quality of drug therapy among older patients at hospital admission appears to be suboptimal. A more accurate estimate of the problem could be obtained through a prospective study where drug regimens are correlated with symptoms and reason for admission. Additional studies are also needed in the outpatient setting. Such studies could provide more accurate evidence and assist policy making towards improved quality of drug prescribing for a growing number of older patients.

Keywords: elderly, quality indicators, hospitalization, drugs, inappropriate prescribing

Correspondence: Anna Birna Almarsdóttir, annaba@hi.is 